\title{
Thus Spoke Judge Siegfried: An Interpretive Understanding of Law and Morality
}

\author{
Chen Xu \\ Post-doctoral Research Center, China University of Political Science and Law, Beijing 100088, \\ China \\ Sephy0826@163.com
}

Keywords: Concepts and Conceptions; Constructive Interpretation; Evil Law is (not) Law; Law and Morality.

Abstract: An interpretive approach claimed by Ronald Dworkin is a crucial key to understand the relation between law and morality. Dworkin has separated ideas of "legal concepts" and "legal conceptions", according to which law is different from morality. But he also claimed that contents of law and morality actually depend on each other, if one takes an interpretive attitude to consider their differences. And with interpretive attitude and its idea "constructive interpretation", a better understanding of classical puzzle of "evil law is(not)law" will be possible for jurisprudence and a better interpretation to particular legal practice will be easier to achieve.

\section{Introduction}

It may be over-simplified to conclude Ronald Dworkin's argument about law and moral as “they are necessary connected”. It may also be over-simplified to conclude Separation Thesis, proposed by legal positivists, as "there is no necessary conceptual connection between law and moral". ${ }^{1}$ Dworkin engaged legal positivists in a far more complex way as long as his interpretive theory enhanced by claims in his fine work Law's Empire.

This paper aims to discuss disputes that exist in the fil ed of law and moral by Dworkin's idea of constructive interpretation. It will lead us back to a classical puzzle of jurisprudence, known as evil law is (not) law in twentieth century. In solving this puzzle, Dworkin shaped a German Judge Siegfried, and this paper wish to discuss Dworkin's criticism to legal positivists by reconsidering Judge Siegfried's situation.

\section{The Separation Thesis}

As their founder John Austin once claimed, Legal positivists' basic position on law and moral is the Separation Thesis: "the existence of law is one thing; its merit or demerit is another. Whether it

\footnotetext{
${ }^{1}$ See H. L. A Hart, The Concept of Law, P. Bulloch and J. Raz, Oxford: Clarendon Press, 1994, p.250; Jules. L. Coleman, “Beyond Inclusive Legal Positivism”, Ratio Juris. 2009, 22( 3), pp. 359-94; W. J. Waluchow, Inclusive Legal Positivism, Oxford: Clarendon Press, 1994; See Also Joseph Raz, The Authority of Law, Oxford: Clarendon Press, 1979, pp.37-53; S. J. Shapiro, “Plans, and Practical Reason” , Legal Theory, 2002, 8 , pp. 387-441.
} 
be or be not is one enquiry; whether it be or be not conformable to an assumed standard, is a different enquiry." It shows clearly what legal positivists stand for, a denial to the necessary conceptual connection between law and moral.

It is a simple, however, not a meaningless separation. In H. L. A. Hart's version of the Grudge Informer, ${ }^{2}$ should a judge found that informer guilty just by virtue of justice or Natural Law? Gustav Radbruch, after his reflection on what German lawyers do under the Nazi Regime, had held legal positivism accountable for this shocking incident of inhumanity. Hart, on the contrary, argued for legal positivism's position in a impartial, neutral way. He claimed that two kinds of judgement must be distinguished: one is that people who lives under the Nazi Law have no obligation to obey them, for Nazi laws, due to their excessive wickedness, are not laws at all; the other is that Nazi laws are laws on all accounts, but they are simply too wicked to be obeyed. The major difference between these two judgements is whether we should use abstract ethics code to identify a statue's (or a sentence's) legal validity. Hart argued for his doctrine of separation repeatedly by claiming that laws are laws not because they have some ethical characters which people prefers.

\section{Concepts and Conceptions of Law}

We may be convinced by Hart's argument, but does the factual separation thesis really have any meaningful point in legal practice? Dworkin's answer to this question is more complex than just saying "no". He considers Hart's theory about the concept of law as a semantics thesis and summarize its main objective as inquiring shared common rules people apply in using certain words. ${ }^{3}$ This semantics thesis, according to Dworkin, is a over-simplification of the complexity of linguistic practice, for it provides only a abstract description of shared common rules we apply in using the concept of law.

Then can we find a more convincing theory to understand the relationship law and moral? It is necessary to introduce some theoretical premises raised by Dworkin. In his fine work Law's Empire, a interpretive understanding of law which consists of terms like " constructive interpretation" , " stages of interpretation” , “ concepts of law” and " conceptions of law” are used as a reply to positivists' semantics approach. ${ }^{4}$ As Dworkin claimed, law and moral are different not because of different rules which we apply in using these two words, but because their contents depend on each other. He further argued: in almost every community, moral tradition, which contains ethical codes and guidance of behavior, and legal system, which is the combination of statues, sentences, courts and legislative institution, are obviously different from the other; however, legal system or laws are not attached to this community passively, but will inevitably become a organic part of community's common history and shared lives by granting people rights and obligations.

So we might conclude that the interaction between law which grants rights and obligations and moral tradition which is the sediment of history is a conception of law that is yet to be interpreted. And, for one concept of law, its conceptions vary from each other. ${ }^{5}$ To be more specific, the interaction between law and moral, in Dworkin's Anglo-American legal community, can be found in the interaction between political virtue, legislative principles and adjudicative principles: legislative principles demand that law speaks coherently with " one voice" ${ }^{6}$ according to the consensus of political virtues which is found in community's history and legal practice; adjudicative

\footnotetext{
${ }^{2}$ H. L. A. Hart, "Positivism and the Separation of Law and Morals", Harvard Law Review, 1958, 71(4), pp.593-629.

3 Ronald Dworkin, Law's Empire, Harvard University Press, 1986, pp. 33-35. 43-46, 68-70.

4 Ronald Dworkin, Law's Empire, Harvard University Press, 1986,, pp. 45-87.

5 Ronald Dworkin, Law's Empire, Harvard University Press, 1986, pp. 96-97.

6 Ronald Dworkin, Law's Empire, Harvard University Press, 1986, pp. 176-224.
} 
principles demand that judges apply and reflect on their convictions about political virtue and law to seek best interpretations of hard cases where words or meanings of law are vague or indeterminate. $^{7}$

\section{The Situation of Judge Siegfried}

In order to reply to legal positivists, we shall now discuss the separation thesis under Dworkin's interpretive approach. Legal positivists insists that laws or legal systems are laws or legal systems, regardless of their moral defects, as long as they meet certain factual or empirical conditions. Dworkin take this separation thesis as a conception of law which emphasizes on a empirical approach to the research of concepts of law.

We must introduce Judge Siegfried to explain Dworkin's argument. We assume, daringly, that Judge Siegfried, despite of his position in a wicked regime, approves a concept of law which claims law should provide national coercion with justification. It is obvious that he need not to ignore or deny basic fact that Nazi laws, regardless of their wickedness, are laws according to certain empirical standards. For he uses the word " law" according with shared standards which are determined by Ludwig Wittgenstein' s form of life that takes shape in human's daily practice. ${ }^{8}$ So such shared standards are the commonest criterion by which we judge whether laws exist. Judge Siegfried may claims: Nazi laws are laws, regardless of its wickedness, for they meet shared standard of human language; there is no reason for us to deny their factual existences.

But does Judge Siegfried make a conceptual mistake if he also approves, according to his own political convictions, "evil law is not law"? Dworkin argues that it is the very one-sided view of legal positivists which forces Judge Siegfried must deny other possible conception in a all-or-nothing way. Does Judge Siegfried make a conceptual mistake, furthermore, if he refuses to approve that Nazi laws are laws because he believes that Jewish-discrimination statues of Nazi law lack equality which laws must have. The judge now are facing two entirely different question: on one hand, he might thinks that Nazi laws are fibers constitute a whole rope of human's language practice, so in pre-interpretive sense Nazi laws and laws in other country are laws, for they all meet those shared standards mentioned above; on the other hand, if the question is "are laws without certain value or virtue laws", he will probably argue that "they are not laws because of their wickedness, and this has nothing to do with its empirical existence”. ${ }^{9}$ Dwokin concludes that Judge Siegfried's second judgement is also a conception of law, which should not be taken as a mistake without further consideration. Which conception is better between two attitudes, the abstract thesis of legal positivism and the value-based claim, depends on interaction between interpreter and his object.

The flexibility of legal language requires jurisprudence to take different pint of view to consider different question. A Legal positivist may say " it is not true or not a fact that Nazi laws are not laws" or " Judge Siegfried had made a mistake because he ignore the shared rules he and other Germans had always followed”. However, Siegfried' s second judgement is not a semantic claim which is eager to catch facts of shared language rules, but a skeptical interpretive statement which deepens his own political conviction by proposing a conception of law---- laws without certain virtues or values are not laws. He does believe, in pre-interpretive sense, law and moral are two different categories and he need not to deny this. But he can also propose a conception which might be better than and different from legal positivism without rejecting plain facts no one can deny.

\footnotetext{
7 Ronald Dworkin, Law's Empire, Harvard University Press, 1986, pp. 225-276

8 Ronald Dworkin, Law's Empire, Harvard University Press, 1986, p.63.

9 Ronald Dworkin, Law's Empire, Harvard University Press, 1986, pp.69-103.
} 


\section{Conclusion}

Just as Dworkin claimed, he and Hart both agree that law and moral are two different concept. The disagreement is, however, whether interpretation of law in a certain legal community depends on what moral requires social members to do. Dworkin considers legal positivism as a conception of law, also known as conventionalism, and concludes that jurisprudence must seek more than semantic shared rules. That is why he believes his interpretive approach will be a better interpretation than legal positivism if legal theory and legal practice are integrated by what he calls constructive interpretation. ${ }^{10}$

\section{References}

[1] H. L. A Hart, The Concept of Law, 2nd ed. P. Bulloch and J. Raz, Oxford: Clarendon Press, 1994.

[2] W. J. Waluchow, Inclusive Legal Positivism, Oxford: Clarendon Press, 1994.

[3] Joseph Raz, The Authority of Law, Oxford: Clarendon Press, 1979.

[4] Ronald Dworkin, Law's Empire, Harvard University Press, 1986.

[5] Ronald Dworkin, Justice in Robes, Harvard University Press, 2006.

[6] Jules. L. Coleman, “Beyond Inclusive Legal Positivism”, Ratio Juris, 2009, 22(3), pp. 359-94.

[7] S. J. Shapiro, “Plans, and Practical Reason”, Legal Theory, 2002, 8, pp. 387-441.

[8] H. L. A. Hart, "Positivism and the Separation of Law and Morals", Harvard Law Review, 1958, 71(4), pp.593-629.

[9] Ronald Dworkin, “Objectivity and Truth: You'd Better Believe It”, Philosophy and Public affairs, 1996, 25(2), pp.87-139.

\footnotetext{
${ }^{10}$ Ronald Dworkin, Law's Empire, Harvard University Press, 1986, pp.114-151.
} 